\title{
Nutritional quality and sensory attributes of date palm spathes beverage supplemented with pollen grains
}

\author{
Jozaa Zaidan ALTAMIMI ${ }^{1}$, Nora Abdullah ALFARIS ${ }^{1}$ (D), Lujain Abdulaziz ALMOUSA ${ }^{1}$, \\ Hind Abd-allah ABU-HIAMED ${ }^{1}$, Nawal Abdullah ALBADR ${ }^{2}$, Fatima Ali ALGHAMDI ${ }^{1 *}$
}

\begin{abstract}
The aim of this study was to fortify date palm spathes beverage with pollen grains. The nutritional quality and sensory attributes of the developed products were evaluated. The results showed that pollen grains significantly $(\mathrm{P}<0.05)$ influenced the nutritional and sensory qualities of date palm spathe beverages. With minor exceptions, fortification of spathe beverage with pollen grains significantly $(\mathrm{P}<0.05)$ increased the levels of protein, carbohydrate, fat, total dissolved solid (TDS), magnesium $(\mathrm{Mg})$, iron $(\mathrm{Fe})$, selenium (Se) and vitamins A, E, and C as well as the antioxidant activity (DPPH and FRAP) especially with 5\% pollen grains. However, fortification reduced the levels of turbidity, boron (B), nickel (Ni), copper ( $\mathrm{Cu}$ ), zinc ( $\mathrm{Zn})$, and molybdenum (Mo). In terms of the colour, taste, and texture of the beverages, the panellists has no preference between the control beverage and $5 \%$ pollen grains. The highest overall acceptance was found for the control beverages without pollen grains, followed by those with 5\% pollen grains. Overall, the inclusion of pollen grains in the formulation of date palm spathe beverage could enhance the nutritional quality without substantially influencing the sensory acceptability of the beverages.
\end{abstract}

Keywords: date palm spathe beverage; nutritional quality; pollen grains; trace minerals; vitamins.

Practical Application: Product new beverage using date palm spathe.

\section{Introduction}

Date palm (Phoenix dactylifera $\mathrm{L}$.) is a versatile tree that is considered part of the national heritage of many Middle Eastern countries due to its numerous potential applications in the production of food, animal fodder, shelter, rope, baskets, hats, timber products, and traditional medicines used by local populations (Al-Yahya \& Manickavasagan, 2012; Chao \& Krueger, 2007). In recent decades, the cultivation and demand for date palm have greatly increased because of its numerous applications and high tolerance of harsh environmental conditions such high temperatures, limited water resources, and high soil and water salinity. Saudi Arabia is the fourth highest producer of dates with an annual production of 755 thousand tons in 2017 (Food and Agriculture Organization of the United Nations, 2017). Before date palm pollination, male and female date palm flowers (inflorescence) are enclosed in a hard envelope-like structure known as a spathe. During pollination, the spathe is split open to expose the mature flowers for the pollination process (Gammoudi et al., 2016). Annually, large amounts of date palm spathes are produced in Saudi Arabia, and they are considered one of major date palm waste products (Al-Zoreky \& Al-Taher, 2019). The utilization of date palm spathes as a food source is of major importance from both nutritional and economic perspectives.

Date palm pollen is the male reproductive white to yellow soft powder of palm flowers (Abdi et al., 2017). In traditional medicine, date palm pollen grains are commonly used for the treatment of male and female infertility (Hassan, 2011). Previous investigations have demonstrated that it contains several important phytochemicals, such as sterols, triterpenes, saponins, proteins, carbohydrates, glycosides, phenolic acids, flavonoids, procyanidins, vitamins and essential minerals (Hassan, 2011; Metwaly et al., 2017; Tahvilzadeh et al., 2016). In date producing countries, such as Saudi Arabia, thousand of tones of date palm pollen is produced annually, and a substantial amount ends up as waste.

In traditional medicine in the Arabian Peninsula and other part of Asia, a distillate from date palm spathes is used for the treatment of diarrhoea, skin disorders, peptic ulcers, and rheumatoid arthritis in addition to being used as a nerve tonic and a tranquilliser (Farboodniay et al., 2016; Hamedi et al., 2013). The distillate is also used as a flavouring agent in coffee, tea, and water as well as in other foods (Al-Zoreky \& Al-Taher, 2015). Previously, the chemical composition of date palm spathe contain phenols, flavonoids, steroids, triterpene steroids, oils, flavonoids, 3,4-dimethoxytoluene, 2,4-dimethoxytoluene, and 5,9-undecadien-2-one, $\beta$-caryophyllene, $\mathrm{p}$-cresyl methyl ether, and caryophyllene oxide (Al-Yahya, 1986; Al-Zoreky \& Al-Taher, 2015, 2019; Farboodniay et al., 2016; Hamedi et al., 2013). Date palm spathe extracts and essential oils also exhibit antioxidant activity (Al-Zoreky \& Al-Taher, 2015, 2019; Farboodniay et al., 2016). In addition, its essential oil possesses 
antimicrobial activity against various pathogenic microbes, such as Listeria monocytogenes, Escherichia coli, Staphylococcus aureus, Staphylococcus saprophyticus, Salmonella enterica subsp. enterica serovar Enteritidis, Pseudomonas aeruginosa, Proteus vulgaris, Bacillus subtilis, and Candida albicans (Al-Yahya, 1986; Al-Zoreky \& Al-Taher, 2015, 2019; Demirci et al., 2013). Moreover, spathe oil has shown repellent activity against yellow fever mosquito (Demirci et al., 2013). However, studies on the chemical composition and sensory attributes of date palm spathe water are scarce. Therefore, the main aim of this study was to prepare a date palm spathe beverage, fortify it with date palm pollen grains, and evaluate its nutritional qualities and sensory attributes.

\section{Materials and methods}

\subsection{Materials}

Fresh date palm spathes (from male and female trees) and pollen grains were obtained from the Date Palm Institute, Al-Ahsa, KSA, during the 2019 pollination season (January and February). Five days ages spathes were washed thoroughly with distilled water to remove dust and impurities. Thereafter, they were cut into small cubes $(3 \mathrm{~cm} \times 2 \mathrm{~cm})$, sealed in polyethylene bags and stored at $4{ }^{\circ} \mathrm{C}$ until extraction of the pollen water. Date palm pollen grains were collected, dried at room temperature, and kept as a powder at $4{ }^{\circ} \mathrm{C}$ until used for fortification of the beverage. All chemicals were of analytical grade and were obtained from Sigma Aldrich.

\subsection{Preparation of the date palm pollen spathe beverage}

Twenty kilograms of fresh date palm spathes were put into a fabricated steam distillation unit (Date Palm Institute, Al-Ahsa, KSA), and then $165 \mathrm{~L}$ of water was added. The distillation temperature was initially set at $180^{\circ} \mathrm{C}$ until distillation started, and the temperature was reduced to $100{ }^{\circ} \mathrm{C}$ to mimic the traditional procedure used for spathes beverage preparation. Using high temperature to help produce a large amount of high-quality distillate but this may increase opportunities for accidents and burn of the spathe, So decreasing of the temperature will help to keep controlling and safety the distillery. The resulting beverage was collected and filtered through filter paper to remove impurities. The filtered beverage was poured into autoclaved glass bottles, properly sealed, and stored in a refrigerator at $5{ }^{\circ} \mathrm{C}$ until analysis.

\subsection{Preparation of the date palm spathe beverage containing $3 \%$ and $5 \%$ pollen grains}

Mixture of spathes beverage and $3 \%$ and $5 \%$ pollen grains were also prepared to determine the impact of pollen grains on the quality of the beverages. $19.4 \mathrm{~kg}, 19.0 \mathrm{~kg}$ of date palm spathes was mixed with $0.6 \mathrm{~kg}, 1.0 \mathrm{~kg}$ of pollen grains in the steam distillation unit, and then $165 \mathrm{~L}$ of water was added to the distillation unit for the preparation of beverages containing $3 \%, 5 \%$ pollen grains, respectively . All beverages were kept at $5{ }^{\circ} \mathrm{C}$ until analysis.

\subsection{Determination of the Total Dissolved Solids (TDS) and turbidity (NTU) and microbiological analysis}

The TDS and TNU in the beverage samples were also assessed for the developed date palm spathe-based beverages according World Health Organization (1996) guidelines for drinking-water quality, TDS measured using an ORION 5-STAR pH ISE conductivity meter with a conductivity cell (Thermo Scientific, London, UK). The turbidity (NTU) was measured using spectrophotometrically (Mini 1240UV-VIS spectrophotometer Shimadzu, Kyoto, Japan).

All beverages were analysed for microbial load (bacterial counts, Escherichia coli, moulds and yeasts) according to American Public Health Association (1992) and Kang et al. (2003). using VIDAS and Biomerieux (Paris, France) microbial analysis tools. Media selective for each microbe was used, and the cultures were incubated at $35^{\circ} \mathrm{C}, 30^{\circ} \mathrm{C}$, and $42^{\circ} \mathrm{C}$ for $24 \mathrm{~h}$ for coliform bacteria, E. coli, and Salmonella, respectively, whereas that of yeast and moulds were incubated at $25^{\circ} \mathrm{C}$ for $3 \mathrm{~d}$. Results were expressed as $\mathrm{CFU} \mathrm{g}^{-1}$.

\subsection{Determination of the total protein, carbohydrate, and fat}

The total protein in the beverage samples was determined using the Biuret method as described by Keppy \& Allen (2009), and the absorbance of the samples and standards was measured at $540 \mathrm{~nm}$ using a mini 1240 UV-VIS spectrophotometer (Shimadzu, Kyoto, Japan). The protein contents in the samples were calculated using the linear equation $\left(\mathrm{r}^{2}=0.996\right)$ generated using standards with known protein concentrations. The total carbohydrate contents were determined using a phenol-sulfuric acid colorimetric method as described previously (Nielsen, 2010). The total fat was determined using a gravimetric method described by Phillips et al. (1997).

\subsection{Determination of vitamins and minerals}

Vitamins $C$ and $\mathrm{E}$ were determined using a spectrophotometric method as described by Saeed et al. (2018). Vitamin A was determined using a spectrophotometric method based on its interaction with TCA in dichloromethane as described previously (Kamangar \& Fawzf, 1978).

The mineral concentration in the beverage samples was determined using an inductively coupled plasma/mass spectrometer (ICP/MS). External standards of elements were used for calibration $\left(\mathrm{r}^{2}=0.998-0.999\right)$ and quantification of the minerals in the samples.

\subsection{Sensory analysis}

The sensorial quality (colour, appearance, texture, flavour, and overall acceptance) of each beverage product were measured using a 10-points unstructured Descriptive Analysis scale $(1=$ extremely dislike and $10=$ extremely like) (Singh-Ackbarali \& Maharaj, 2014). A panel of 29 trained panellists from Date Research Institute, Al-Ahsa, KSA, were asked to assess the sensory quality of the beverages. Samples were numbered using three digit codes and were served randomly to the panellists. Water was provided to rinse the mouth before and 
throughout the analysis sessions, and normal light was used in the sensory room.

\subsection{Statistical analysis}

The data were analysed using SPSS statistical software (Version 22.0), and the results are expressed as the mean \pm standard deviation. Analysis of variance between groups was assessed using one-way ANOVA followed by Duncan's multiple range test at a significance level of $\mathrm{P} \leq 0.05$.

\section{Results and discussion}

\subsection{The microbial and physical properties of the date palm pollen spathe beverages fortified with 3 and $5 \%$ pollen grains}

The hygienic quality of each of the date palm spathe-based beverages was assessed by different microbiological tools. The results indicated that the products were of good hygienic quality, as no microbial growth (bacteria, moulds, and yeast) was observed in any of the beverages (data not shown). This quality could be attributed to the heating and controlled hygienic processes used during the production of the date palm beverages as well as to the antimicrobial potential of the date palm spathe. Similarly, previous investigations on date palm spathe oils and extracts have indicated that they exhibit antimicrobial activity against several pathogenic microbes (Al-Yahya, 1986; Al-Zoreky \& Al-Taher, 2015, 2019) and yellow fever mosquitoes (Demirci et al., 2013). Date palm pollen grains also possess antimicrobial activity against several bacterial and fungal strains (Daoud et al., 2019).

Fortification of the beverages with increasing concentrations of grains from 3 to $5 \%$ gradually increased the TDS of the beverage, and the increase in the TDS with increasing pollen grains could be due to high trace minerals in the pollen grains (Shihab, 2018). The turbidity was also reduced from 10.4 in the control beverage to 8.5 in beverages containing $5 \%$ pollen grains. The reduction in turbidity as the percentage of pollen grains increased could be due to the complexation of the solid particles of the spathes and the pollen grains, forming large complexes that were removed during the filtration of the date palm spathe-based beverages.

\subsection{Chemical composition of the date palm pollen spathe beverage fortified with 3 and $5 \%$ pollen grains}

The total protein, carbohydrate and fat contents of the date palm spathe-based beverages fortified with 3 and $5 \%$ date palm pollen grains are presented in Table 1. The highest protein, carbohydrate and fat contents were observed in the pollen spathe beverage fortified with $5 \%$ pollen grains, whereas the lowest levels were found in the pollen spathe beverage without pollen grains $(\mathrm{P}<0.05)$. Generally, the addition of pollen grains to the pollen spathe extract significantly $(\mathrm{P}<0.05)$ increased the protein, carbohydrate and fat contents in the products. The increase in the protein, fat, and carbohydrate contents in the date palm beverages following the addition of pollen grains could be attributed to the high values of these important components in date palm pollen grains. A previous report indicated that date palm pollen grains contain approximately $31.11 \%$ protein, $13.41 \%$ carbohydrates, and $20.74 \%$ oils (Hassan, 2011). In addition, another report showed that date palm pollen contains $7.7,19.45$, and $26.25 \%$ fat, protein, and carbohydrate, respectively. The variations in the chemical constituents of date palm pollen grains and spathes could be due to the differences in genetic makeup, environmental conditions, soil fertility, and agronomical practices. Collectively, the results of this study demonstrate that the inclusion of pollen grains in pollen spathe beverage is recommended to enhance the nutritional quality of this important beverage.

\subsection{Vitamin and elements contents in date palm pollen spathe beverages fortified with 3 and $5 \%$ pollen grains}

The contents of vitamins $\mathrm{A}, \mathrm{E}$, and $\mathrm{C}$ in the date palm spathe-based beverages fortified with 3 and $5 \%$ pollen grains are presented in Table 2. Significant $(\mathrm{P}<0.05)$ differences in the contents of vitamins $\mathrm{A}, \mathrm{E}$, and $\mathrm{C}$ were observed between the three beverages. Apparently, fortification of the spathe beverages with $5 \%$ date palm pollen grains significantly improved the contents of vitamins $\mathrm{A}, \mathrm{E}$, and $\mathrm{C}$ in the products, as the highest levels of these vitamins were found in the beverage containing $5 \%$ pollen grains $(P<0.05)$. Increases in the vitamin $A, E$, and $C$ contents in date palm spathes beverages with increasing pollen grain concentration is expected because date palm pollen grains are known to contain substantial quantities of these vitamins (Hassan, 2011). The findings of the current study indicated that

Table 1. Chemical composition (mg/L) of the date palm spathe beverages (DPSPB) fortified with 3 and $5 \%$ pollen grains (PG).

\begin{tabular}{cccc}
\hline Beverage samples & Total Protein & Total Carbohydrate & Total Fat \\
\hline DPSPB & $220.00 \pm 5.57^{\mathrm{c}}$ & $138.00 \pm 4.36^{\mathrm{b}}$ & $172.00 \pm 4.58^{\mathrm{c}}$ \\
DPSPB + 3\% PG & $239.67 \pm 5.03^{\mathrm{b}}$ & $149.00 \pm 9.54^{\mathrm{b}}$ & $192.00 \pm 4.00^{\mathrm{b}}$ \\
DPSPB +5\% PG & $800.00 \pm 13.23^{\mathrm{a}}$ & $510.00 \pm 10.44^{\mathrm{a}}$ & $650.00 \pm 7.00^{\mathrm{a}}$ \\
\hline
\end{tabular}

Values are the mean (mean \pm SD) of three replicates. ${ }^{a-c}$ Means sharing similar superscript letters in each column are not significantly different at $\mathrm{P}<0.05$.

Table 2. Vitamin contents (mg/L) in date palm spathe beverages (DPSPB) fortified with 3 and 5\% pollen grains (PG).

\begin{tabular}{cccc}
\hline Beverage samples & Vitamin C & Vitamin A & Vitamin E \\
\hline DPSPB & $1.67 \pm 0.21^{\mathrm{b}}$ & $0.03 \pm 0.003^{\mathrm{b}}$ & $0.025 \pm 0.002^{\mathrm{b}}$ \\
DPSPB + 3\% PG & $1.83 \pm 0.21^{\mathrm{b}}$ & $0.04 \pm 0.003^{\mathrm{b}}$ & $0.028 \pm 0.020^{\mathrm{b}}$ \\
DPSPB +5\% PG & $6.10 \pm 0.26^{\mathrm{a}}$ & $0.11 \pm 0.015^{\mathrm{a}}$ & $0.100 \pm 0.284^{\mathrm{a}}$ \\
\hline
\end{tabular}

Values are the mean (mean $\pm \mathrm{SD}$ ) of three replicates. Means sharing similar superscript letters in each column are not significantly different at $\mathrm{P}<0.05$. 
Table 3. minerals $(\mu \mathrm{g} / \mathrm{L})$ in date palm spathe beverages (DPSPB) fortified with 3 and $5 \%$ pollen grains (PG).

\begin{tabular}{|c|c|c|c|c|c|c|c|c|c|}
\hline Samples & Bo & $\mathrm{Mn}$ & $\mathrm{Fe}$ & Co & $\mathrm{Ni}$ & $\mathrm{Cu}$ & $\mathrm{Zn}$ & $\mathrm{Se}$ & Mo \\
\hline DPSPB & $3.91 \pm 0.24^{\mathrm{a}}$ & $3.00 \pm 0.07^{\mathrm{c}}$ & $13.63 \pm 0.83^{c}$ & $0.30 \pm 0.12^{\mathrm{a}}$ & $1.90 \pm 0.02^{\mathrm{a}}$ & $3.92 \pm 0.04^{\mathrm{a}}$ & $15.57 \pm 3.15^{\mathrm{a}}$ & $0.28 \pm 0.10^{\mathrm{ab}}$ & $0.79 \pm 0.16^{\mathrm{a}}$ \\
\hline DPSPB $+3 \%$ PG & $2.68 \pm 0.19^{b}$ & $7.11 \pm 0.16^{\mathrm{a}}$ & $18.79 \pm 0.29^{a}$ & $0.31 \pm 0.00^{\mathrm{a}}$ & $1.61 \pm 0.02^{\mathrm{a}}$ & $2.37 \pm 0.11^{b}$ & $5.99 \pm 0.63^{b}$ & $0.40 \pm 0.09^{\mathrm{a}}$ & $0.25 \pm 0.02^{b}$ \\
\hline $\mathrm{DPSPB}+5 \% \mathrm{PG}$ & $2.22 \pm 0.12^{\mathrm{c}}$ & $4.10 \pm 0.45^{b}$ & $17.30 \pm 0.10^{b}$ & $0.18 \pm 0.00^{\mathrm{a}}$ & $1.48 \pm 0.14^{\mathrm{a}}$ & $1.12 \pm 0.03^{c}$ & $1.38 \pm 0.32^{c}$ & $0.26 \pm 0.15^{b}$ & $0.52 \pm 0.18^{\mathrm{ab}}$ \\
\hline
\end{tabular}

Values are the mean (mean \pm SD) of three replicates. Means sharing similar superscript letters in each column are not significantly different at $\mathrm{P}<0.05$.

Table 4. Sensory attributes of date palm spathe beverages (DPSPB) fortified with 3 and 5\% pollen grains (PG).

\begin{tabular}{lccccc}
\hline \multicolumn{1}{c}{ Beverages } & Colour & Flavour & Texture & Appearance & Overall acceptance \\
\hline DPSPB & $8.64 \pm 2.00^{\mathrm{a}}$ & $8.34 \pm 2.92^{\mathrm{a}}$ & $8.69 \pm 1.80^{\mathrm{a}}$ & $7.86 \pm 1.77^{\mathrm{ab}}$ & $8.38 \pm 2.50^{\mathrm{a}}$ \\
DPSPB + 3\% PG & $7.07 \pm 1.51^{\mathrm{b}}$ & $3.69 \pm 2.30^{\mathrm{b}}$ & $5.83 \pm 1.71^{\mathrm{b}}$ & $7.66 \pm 1.05^{\mathrm{b}}$ & $4.10 \pm 2.83^{\mathrm{c}}$ \\
DPSPB $+5 \%$ PG & $8.86 \pm 1.66^{\mathrm{a}}$ & $7.76 \pm 3.65^{\mathrm{a}}$ & $7.97 \pm 1.59^{\mathrm{a}}$ & $8.93 \pm 1.25^{\mathrm{a}}$ & $6.52 \pm 2.75^{\mathrm{b}}$ \\
\hline
\end{tabular}

Values are the mean (mean \pm SD) of three replicates. Means sharing similar superscript letters in each column are not significantly different at $\mathrm{P}<0.05$.

the fortification of date palm beverages with $5 \%$ pollen grains could improve the nutritional qualities of these beverages.

Table 3 shows the mineral contents in date palm spathe beverages supplemented with 3 and $5 \%$ date palm pollen grains. With the exception of cobalt (Co), statistical analysis showed significant $(\mathrm{P}<0.05)$ differences in the values of all elements between the three beverage products (control spathe beverage without pollen grains, spathe beverage with $3 \%$ pollen grains, and spathe beverage with $5 \%$ pollen grains). The addition of pollen grains to the beverages caused the levels of elements to fluctuate $(\mathrm{P}<0.05)$. Increasing the concentration of pollen grains in the beverages gradually reduced the concentrations of boron (Bo), nickel $(\mathrm{Ni})$, copper $(\mathrm{Cu})$, zinc $(\mathrm{Zn})$, and molybdenum (Mo). However, it increased the contents of

Manganese ( $\mathrm{Mg})$, iron ( $\mathrm{Fe})$ and selenium (Se), especially at $3 \%$ pollen grains $(\mathrm{P}<0.05)$. The variable impacts of pollen grains on the trace minerals in the date palm beverages suggest that this could be due to the interactions of these minerals from both the pollen spathe and pollen grains. The reduction in the levels of some minerals in the beverage with the incorporation of date palm pollen grains could be attributed to the chelation of these minerals with compounds in the pollen grains, such as polyphenols, particularly tannins and phytates, which are found in high levels pollen grains (Al-Samarai et al., 2016; Daoud et al., 2019). However, the increases in $\mathrm{Mg}$, Fe, and $\mathrm{Se}$ with the addition of pollen grains could be due to the high quantities of these minerals in the date palm pollen grains (Al-Samarai et al., 2016; Hassan, 2011). Although the incorporation of date pollen grains into date palm spathe beverage could improve the quantities of some trace minerals, it reduced the levels of others. Overall, pollen grains improved the nutritional qualities of date palm spathe beverage as it increased the most important essential minerals, namely, iron and Manganese.

\subsection{Sensory attributes of date palm pollen spathe beverages fortified with 3 and $5 \%$ pollen grains}

The sensory attributes of date palm spathe-based beverages with and without 3 and $5 \%$ pollen grains are depicted in Table 4 . Statistical analysis of the data showed significant differences in the sensory attributes of the beverages. In terms of the colour, flavour, and texture of the beverages, the panellists showed no preference between the control beverages without pollen grains and those with $5 \%$ pollen grains. The colour, taste, and texture of beverages containing $3 \%$ pollen grains differed significantly from the control and the beverage containing $5 \%$ pollen grains according to the panellists. However, the appearance of the beverage prepared from date palm spathe and fortified with 5\% pollen grains was significantly preferred over those of the other two beverages. The highest overall acceptance was found for the control beverage without pollen grains, followed by that with $5 \%$ pollen grains and that containing 3\% pollen grains. Similarly, improvements in the sensory attributes of honey-wine with pollen grains was found to be uncorrelated with the concentration of pollen grains (Roldán et al., 2011). Apparently, the inclusion of pollen grains in date palm spathe beverage significantly affected the overall acceptance of the product. It is recommended to add flavor compounds to increase the overall acceptance rate as the addition of pollen grains did not affect the color and other sensory characteristics.

\section{Conclusion}

This study reported the development of date palm spathe beverage and its fortification with pollen grains for first time. The chemical composition mineral contents, vitamins A, E, and $\mathrm{C}$ contents of date palm spathes beverages were greatly enhanced by fortification with $5 \%$ pollen grains. Fortification of beverages with pollen grains improved the nutritional quality of the date palm spathe-based beverages with a slight impact on some of the sensory quality characteristics of the product. Further studies should specifically focus on in vivo investigations of the developed beverages in model animals.

\section{Acknowledgements}

The authors wish to thank The Ministry of Environment, Water and Agriculture (MWA) Riyadh, KSA, for the financial assistance provided (T-A-4) to conduct this research. The authors would like to thank H. A. Alhajji, S. A. Al Ali, M. R. ALAli, A. A. AL Shoaker and A. S. AL Mohaemmed from the Date Palm Institute, Al-Ahsa, to Ministry of Environment Water \& Agriculture, KSA, for their help with the distillation. This research was funded by the Deanship of Scientific Research at Princess Nourah bint Abdulrahman University through the Fast-track Research Funding Program 


\section{References}

Abdi, F., Roozbeh, N., \& Mortazavian, A. M. (2017). Effects of date palm pollen on fertility: research proposal for a systematic review. BMC Research Notes, 10, 363. http://dx.doi.org/10.1186/s13104017-2697-3. PMid:28764804.

Al-Samarai, A. H., Al-Salihi, F. G., \& Al-Samarai, R. R. (2016). Phytochemical constituents and nutrient evaluation of date palm (Phoenix dactylifera, L.) pollen grains. Tikrit Journal of Pure Science, 21(1), 56-62.

Al-Yahya, M. A. (1986). Phytochemical and biological studies on saudi medicinal plants part II. The major component of the spathe oil of phoenix dactylifera. Fitoterapia, 57(4), 284-287.

Al-Yahya, R., \& Manickavasagan, A. (2012). An overview of date palm production. In A. Manickavasagan, M. M. Essa \& E. Sukumar (Eds.), Dates: production, processing, food, and medicinal values (pp. 3-12). Boca Raton: CRC Press.

Al-Zoreky, N. S., \& Al-Taher, A. Y. (2015). Antibacterial activity of spathe from Phoenix dactylifera L. against some food-borne pathogens. Industrial Crops and Products, 65, 241-246. http://dx.doi. org/10.1016/j.indcrop.2014.12.014.

Al-Zoreky, N. S., \& Al-Taher, A. Y. (2019). In vitro and in situ inhibition of some food-borne pathogens by essential oils from date palm (Phoenix dactylifera L.) spathe. International Journal of Food Microbiology, 299, 64-70. http://dx.doi.org/10.1016/j.ijfoodmicro.2019.03.018. PMid:30978578.

American Public Health Association - APHA. (1992). Compendium of methods for the microbiological examination of foods. Washington: APHA.

Chao, C. T., \& Krueger, R. R. (2007). The date palm (Phoenix dactylifera L.): overview of biology, uses, and cultivation. HortScience, 42(5), 1077-1082. http://dx.doi.org/10.21273/HORTSCI.42.5.1077.

Daoud, A., Malika, D., Bakari, S., Hfaiedh, N., Mnafgui, K., Kadri, A., \& Gharsallah, N. (2019). Assessment of polyphenol composition, antioxidant and antimicrobial properties of various extracts of date palm pollen (DPP) from two Tunisian cultivars. Arabian Journal of Chemistry, 12(8), 3075-3086. http://dx.doi.org/10.1016/j. arabjc.2015.07.014.

Demirci, B., Tsikolia, M., Bernier, U. R., Agramonte, N. M., Alqasoumi, S. I., Al-Yahya, M. A., Al-Rehaily, A. J., Yusufoglu, H. S., Demirci, F., Başer, K. H., Khan, I. A., \& Tabanca, N. (2013). Phoenix dactylifera L. spathe essential oil: chemical composition and repellent activity against the yellow fever mosquito. Acta Tropica, 128(3), 557-560. http://dx.doi.org/10.1016/j.actatropica.2013.08.003. PMid:23948523.

Farboodniay, J. M. A., Moein, M. R., \& Ahmadi, S. (2016). In vitro free radical scavenging activity and total phenolic and flavonoid content of spathe extracts from 10 cultivar varieties of Phoenix dactylifera $\mathrm{L}$. International Journal of Pharmacognosy and Phytochemical Research, 8(9), 1481-1486.

Food and Agriculture Organization of the United Nations - FAO. (2017). Crops. Rome: FAO. Retrieved from http://www.fao.org/ faostat/en/\#data/QC

Gammoudi, S., Salah, M. B., Ferchichi, A., et al.(2016). Phenological and architectural study of the date palm (Phoenix dactylifera L.) female inflorescence. American-Eurasian Journal of Agricultural \& Environmental Sciences, 16(5), 998-1003.

Hamedi, A., Mohagheghzadeh, A., \& Rivaz, S. (2013). Preliminary pharmacognostic evaluation and volatile constituent analysis of spathe of Phoenix dactylifera L. (Tarooneh). Pharmacognosy Journal, 5(2), 83-86. http://dx.doi.org/10.1016/j.phcgj.2013.02.005.

Hassan, H. (2011). Chemical composition and nutritional value of palm pollen grains. Global Journal of Biochemistry and Biotechnology, 6(1), 1-7.

Kamangar, T., \& Fawzf, A. B. (1978). Spectrophotometric determination of vitamin A in oils and fats. Journal of the Association of Official Analytical Chemists, 61(3), 753-755. http://dx.doi.org/10.1093/ jaoac/61.3.753. PMid:649566.

Kang, D. H., Rhee, M. S., \& Costello, M. (2003). Development of miniaturized four-culture method for the rapid enumeration of four bacterial groups in ground beef. Letters in Applied Microbiology, 36(4), 197-202. http://dx.doi.org/10.1046/j.1472-765X.2003.01273.x. PMid:12641710.

Keppy, N. K., \& Allen, M. W. (2009). The biuret method for the determination of total protein using an evolution array 8-position cell changer (Application Note, No. 51859). Madison: Thermo Fisher Scientific.

Metwaly, A., Ali, G. A., Abdelhamed, K. M., \& Mohsen, M. (2017). Comparing the chemical composition of essential oil from pollen grains of date palm cultivated in madina munawara before and after maturation. Middle East Journal of Applied Sciences, 7(2), 232-238.

Nielsen, S. S. (2010). Phenol-sulfuric acid method for total carbohydrates. In S. S. Nielsen (Ed.), Food analysis laboratory manual (pp. 47-53). Boston: Springer Science. http://dx.doi.org/10.1007/978-1-44191463-7_6.

Phillips, K. M., Tarragó-Trani, M. T., Grove, T. M., Grün, I., Lugogo, R., Harris, R. F., \& Stewart, K. K. (1997). Simplified gravimetric determination of total fat in food composites after chloroformmethanol extraction. Journal of the American Oil Chemists' Society, 74(2), 137-142. http://dx.doi.org/10.1007/s11746-997-0158-1.

Roldán, A., Van Muiswinkel, G. C. J., Lasanta, C., Palacios, V., \& Caro, I. (2011). Influence of pollen addition on mead elaboration: physicochemical and sensory characteristics. Food Chemistry, 126(2), 574-582. http://dx.doi.org/10.1016/j.foodchem.2010.11.045.

Saeed, A. M., Hamzah, M. J., \& Ali, N. J. M. (2018). Sensitive spectrophotometric method for determination of vitamin (C and A). International Journal of Pharmaceutical Sciences and Research, 9(8), 3373-3377.

Shihab, I. M. (2018). Effects of different dietary levels of palm pollen (Phoenix dactylifera L.) on the humoral immunity and hematology of broiler blood. International Journal of Poultry Science, 17(11), 523-528. http://dx.doi.org/10.3923/ijps.2018.523.528.

Singh-Ackbarali, D., \& Maharaj, R. (2014). Sensory Evaluation as a Tool in Determining Acceptability of Innovative Products Developed by Undergraduate Students in Food Science and Technology at The University of Trinidad and Tobago. Journal of Curriculum and Teaching, 3(1), 10-27. http://dx.doi.org/10.5430/jct.v3n1p10.

Tahvilzadeh, M., Hajimahmoodi, M., \& Rahimi, R. (2016). The role of date palm (Phoenix dactylifera L) pollen in fertility: a comprehensive review of current evidence. Journal of Evidence-Based Complementary \& Alternative Medicine, 21(4), 320-324. http://dx.doi. org/10.1177/2156587215609851. PMid:26438718.

World Health Organization - WHO. (1996). WHO guidelines for drinkingwater quality: health criteria and other supporting information (2nd ed., Vol. 2). Geneva: WHO. 